distinct species \& not the female of the cristata? I should have given an account of it long ago if I had been satisfied on this point, which, however, I do not suppose would deter the author of the expected Fauna Americana. If you have found a male having the swelled tail you are perfectly safe, \& I should be glad to see your account of it.

It is true that the generic name is an improper one, but I do not think it ought to be changed; Desmarest complains of the name but he observes that he is afraid d'introduire une nouvelle denomination, \& de contribuer ainsi à compliquer la synonymie.
My concerns here are so numerous that I cannot at present devote as much time to nat. hist. as I could wish, I must therefore defer a further answer to y'r letter for a future opport'y.

In the cristata the hair has been incorrectly stated to be in whorls, Desmarest notices this error. It has $\mathbf{2 2}$ caruncles on the nose. This author's fig. of cristata is very good (Jour. de physique, for Sept'r r8r9) he relies on Illiger's acumen in placing the Talpa longicaudata, Gmel. Long tailed mole of Pennant in this genus, but that species cannot be yours.

\title{
A TACHINID PARASITE OF THE OAK UNICORN PROMINENT.
}

BY C. H. TYLER TOWNSEND, LAS CRUCES, N.M.

The following Tachinid, which I describe from four male specimens, was reared from Schizura unicornis Sm. \& A. by Mr. F. A. Marlatt, at Manhattan, Kans. It has been bred by him, as he writes me, every year for several years past. The specimens are labelled: "From Oak Unicorn Prominent, Ks. Oct."

Masicera schizurae n. sp. ठ․ Black, cinereous. Eyes brown, bare; front about onethird the width of head, a little narrower at vertex than before, rather prominent, cinereous, with a brassy tinge; frontal vitta dark brown or blackish, about one-third the frontal width; frontal bristles descending a little or considerably below base of third antennal joint, some short hairs outside them and on ocellar area; sides of face silvery, bare; face receding, facial depression with a golden tinge, cinereous on the sides of depression; facial ridges with a row of bristles extending nearly or fully half way up the face; vibrissae decussate, inserted nearly on the oral margin; cheeks almost wholly invaded by occipital area, cinereous, black hairy, with row of bristles on lower border; antennae a little shorter than the face, black, second joint not elongate, bristly before, third joint about four times as long as the second; arista rather long and slender, a little thickened on its proximal half, microscopically pubescent, distinctly jointed at base (in one slightly immature specimen distinctly 3-jointed under a high-power lens), black; proboscis short, fleshy, brownish, with large labella; 
palpi well developed, club-shaped, yellow with a reddish tinge, black bristly; occiput cinereous, thickly gray hairy, a bare black band extending from vertex to center, and the orbital margins with a fringe of black bristles. Thorax cinerous, with four black vittae, hairy and bristly, pleurae silvery; scutellum blackish at base, the apical portion broadly pale ocherous, sometimes almost wholly ocherous, with a short apical decussate pair of bristles, a sub-apical pair of macrochaetae more or less decussate and reaching the base of third abdominal segment, a discal pair, and two lateral pairs. Abdomen rather broad, ovate, covered with short bristles; first segment black, a little abbreviated, the other segments broadly or almost wholly silvery at base with hind borders and median vitta shining black, second segment more or less broadly reddish on sides (an immature specimen has the abdomen almost entirely pale reddish); first two segments without macrochaetae, except a lateral marginal one on second segment, but sometimes a median marginal pair also on second segment; third segment with about ten marginal, four to six of which are on upper side; anal segment armed with marginal macrochaetae and bristles; venter largely silvery, the segments black posteriorly. Legs black, femora and tibiae slightly silvery, femora bristly, middle tibiae with some strong bristles, the hind tibiae ciliate on outer edge with a longer bristle beyond middle and two before tip; claws and pulvilli very long, pulvilli smoky whitish. Wings much longer than abdomen, rather broad, without costal spine, grayish hyaline, hardly brownish on costo-basal portion, third vein slightly spined at base; apical cell open, ending distinctly before tip of wing: fourth vein bent in a short curve, without stump or wrinkle, apical cross-vein bowed inward; hind cross-vein more or less curved, much nearer the bow of fourth vein; tegulae watery-white, halteres fuscous.

Length 8.5 to $9 \mathrm{~mm}$.; of wing 7.5 to $8 \mathrm{~mm}$.

Described from four specimens. Kans. This species would belong in Brauer and v. Bergenstamm's genus Argyrophylax, which is separated from Masicera almost solely on the character of the ciliate hind tibiae.

\section{A LIST OF SOME OF THE CATALOGUES AND LOCAL LISTS OF NORTH AMERICAN COLEOPTERA.-II (H.-P.).}

\section{BY JOHN HAMILTON AND SAMUEL HENSHAW.}

33 Haldeman, S. S. Catalogue of the carabideous Coleoptera of southeastern Pennsylvania. (Proc. acad. nat. sci. Phil., I843, v. 2, p. $295^{-298}$.)

210 species are listed.

34 Harrington, W. H. List of Ottawa Coleoptera. (Trans. Ottawa field nat. club, I884, v. 2, p. 67-68.)

I022 species and varieties are listed; the occurrence of about roo additional species is noted.

35 Harrington, W. H. Additions to Canadian lists of Coleoptera. (Can. ent., I 884 , v. 16, p. 44-47:70-73; 96-98: I I7-1 19.)

122 species are listed; a few are not fully identified.
36 Harrington, W. H. On the lists of Coleoptera published by the geological survey of Canada, I842-1888. (Can. ent., I89o, v. 22, p. I35-I40: I53-I60: I84-I9I.) Separate $: 2 \mathrm{I}$ p.

The short lists published in the reports of the Canadian geological survey are here collated; 482 species and varieties are enumerated.

37 Harris, Thaddeus William. Insects. Hitchcock's Report on the geology, etc., of Massachusetts. Amherst, r833. Second edition; Amherst, 1835. Separate; Amherst, 1835 . 

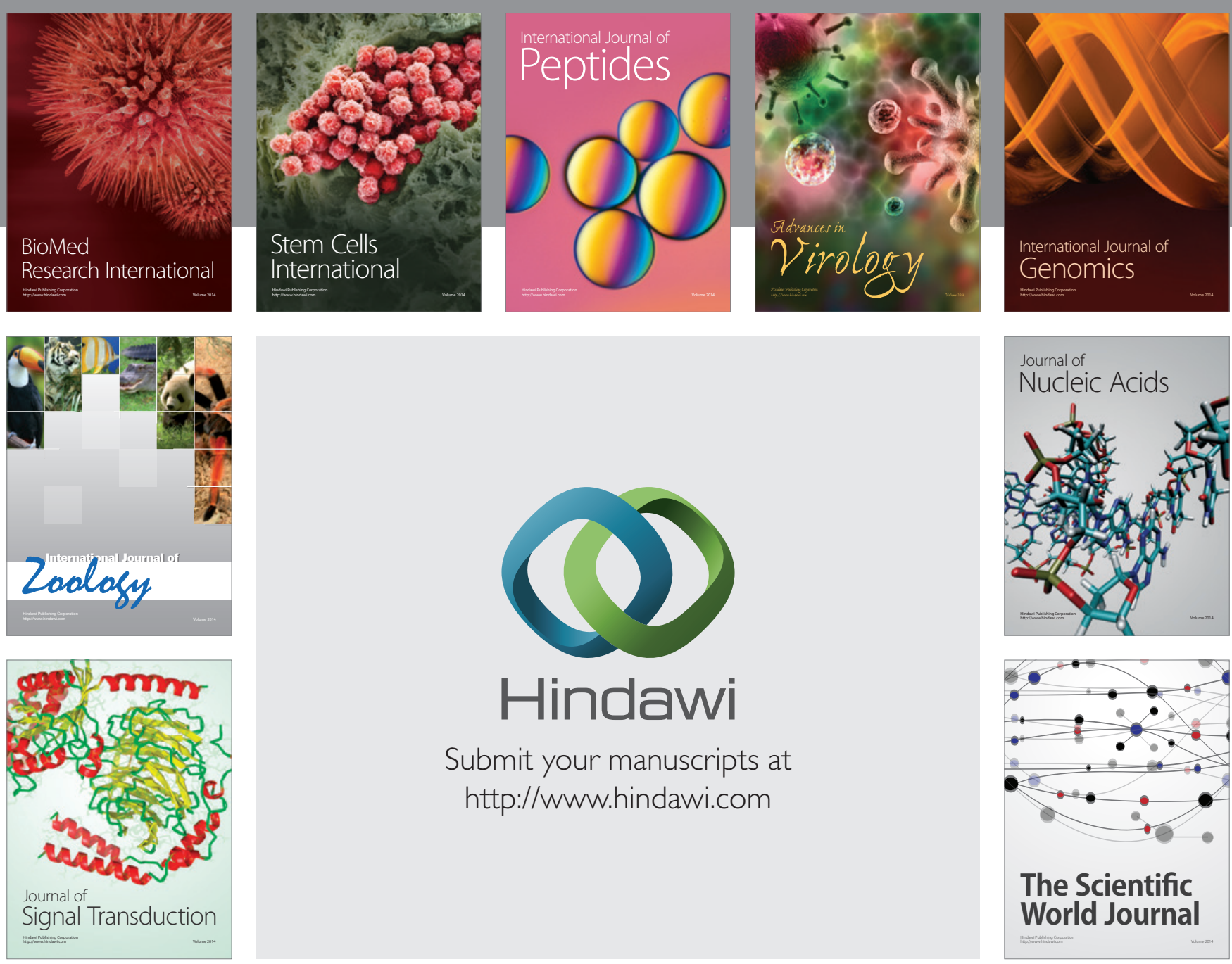

Submit your manuscripts at

http://www.hindawi.com
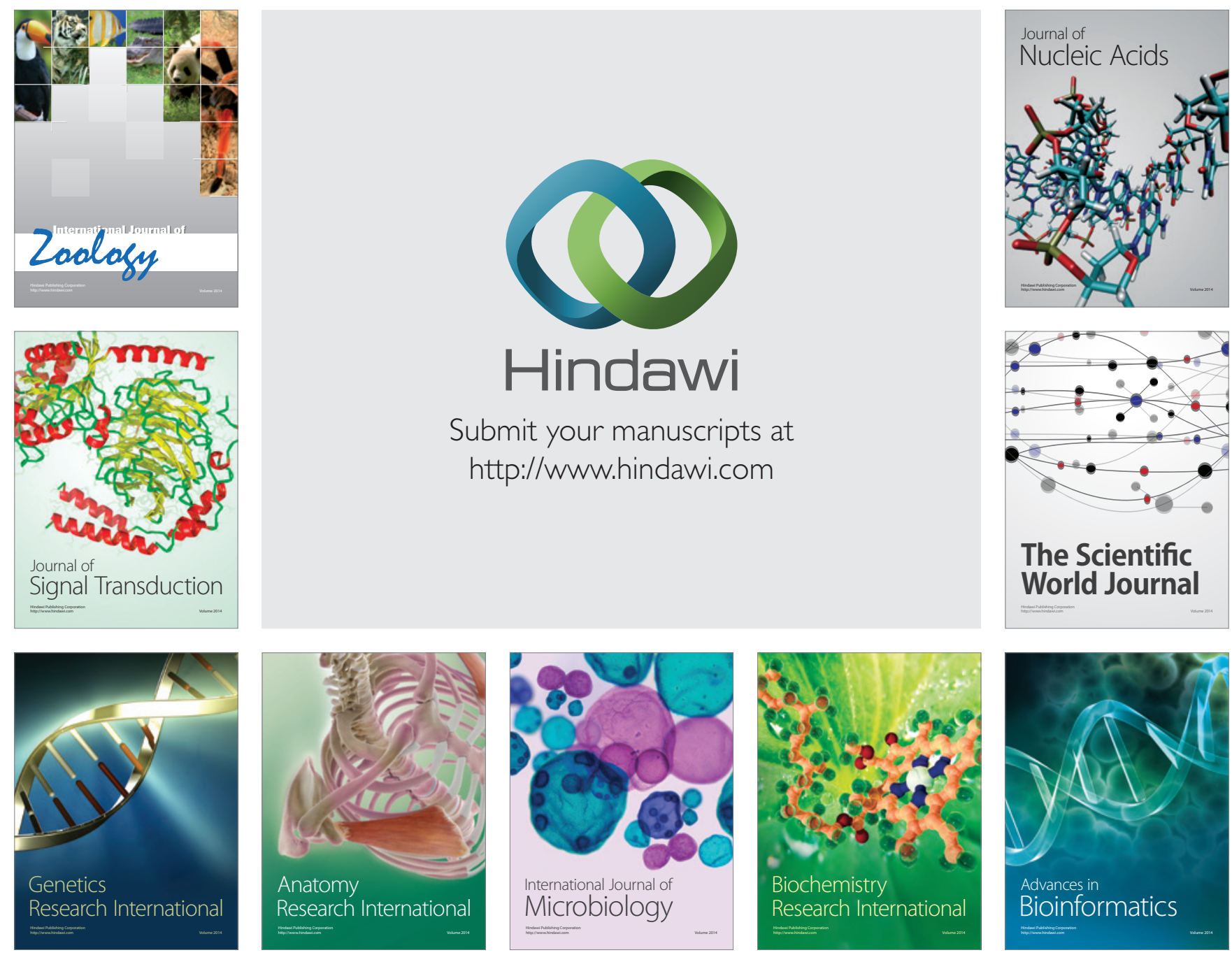

The Scientific World Journal
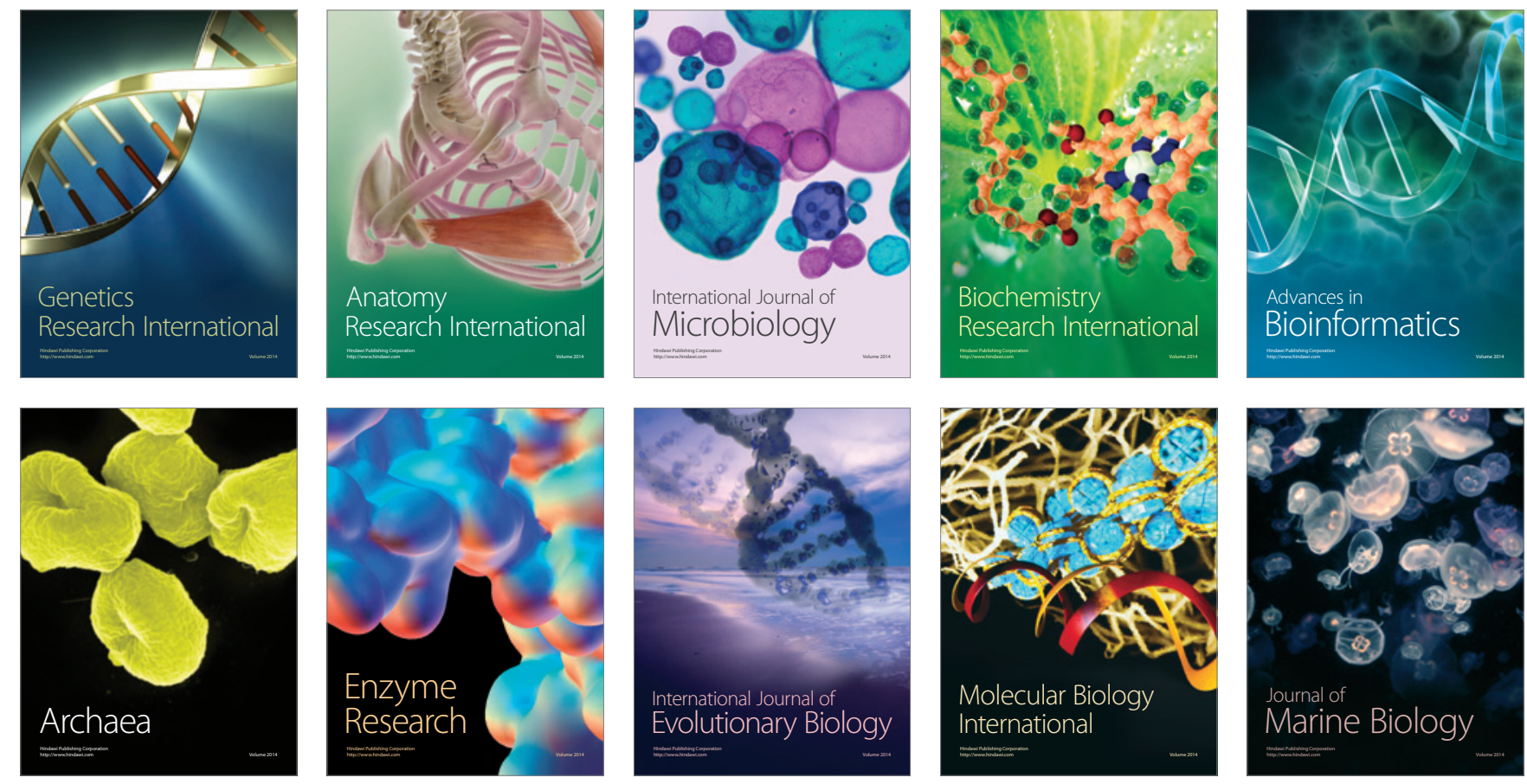